\title{
Analisa Tingkat Kematangan Teknologi Informasi Pada Dinas Komunikasi Dan Informatika Kota Manado Menggunakan Framework COBIT 5 Domain Evaluate, Deirect, Monitor (EDM) dan Deliver, Service, and Support (DSS)
}

\author{
Tedi S. Agoan ${ }^{1}$, Hans F. Wowor ${ }^{2}$, Stanley Karouw ${ }^{3}$ \\ Teknik Informatika Universitas Sam Ratulangi. Manado, Jl. Kampus Unsrat Bahu, Manado 95115 \\ 110216142@student.unsrat.ac.id ${ }^{1}$, hanswowor@unsrat.ac.id ${ }^{2}$, stanley.karouw@unsrat.ac.id ${ }^{3}$
}

\begin{abstract}
Abstrak - Dinas Komunikasi dan Informatika Kota Manado merupakan Instansi yang menangani dan berhadapan langsung masalah terkait dengan Teknologi Informasi skala Kota yang memerlukan perhatian lebih dari pimpinan terlebih dalam penyediaan sarana dan prasarana dan sumber daya manusia. Untuk menilai tingkat kematangan Teknologi Informasi pada instansi penulis menggunakan framework COBIT 5 dengan 2 (dua) domain pilihan yaitu Evaluate, Deirect, Monitor dan Deliver, Service, and Support untuk melihat bagaimana perbandingan antara Governance dan Management.

Hasil dari penelitian ini tingkat kematangan Teknologi Informasi saat ini (as-is), rata - rata mencapai nilai kematangan 3 (Established Proccess) untuk domain Evaluate, Deirect, Monitor dan nilai kematangan 2 (Managed Proccess) Untuk Domain Deliver, Service, and Support, kemudian dari hasil kematangan Teknologi Informasi di berikan pekomendasi perbaikan pada instansi. Instansi mendapatkan ukuran kematangan Teknologi Informasi berdasarkan COBIT 5 serta Rekomendasi yang dapat ditindaklanjuti dalam instansi untuk melakukan perbaikan kedepannya.
\end{abstract}

Kata kunci: COBIT 5, DSS, EDM, Tata kelola, Teknologi Informasi

\section{PENDAHULUAN}

Penggunaan Teknologi Informasi (TI) dalam instansi pemerintahan sangatlah penting dalam menunjang efektivitas pelayanan publik sehingga sangat dibutuhkan pengetahuan serta sumberdaya yang efisien. Dalam Pemerintahan bahkan penggunaan TI dan transaksi elektronik, diatur dalam undang - undang, maka dari itu penggunaan TI dalam instansi perlu dilakukan analisa tingkat kematangan untuk assessment atau tinjauan diri dalam mengetahui kondisi TI dan organisasi serta internal (Boar, 2012), untuk mengetahui sejauh mana manfaat dari penggunaan TI dalam Instansi
Permasalahan teridentifikasi yang sedang dihadapi oleh Dinas Komunikasi dan Informatika Kota Manado mengacu pada Rencana Pembangunan Jangka Menengah Daerah (RPJMD) atau Rencana Stratejik Satuan Kerja Perangkat Daerah (RENSTRA-SKPD) yakni antara lain, Penyediaan sarana dan prasarana yang belum optimal, Belum optimalnya upaya pelayanan informasi publik sehingga mengakibatkan kurangnya partisipasi masyarakat dalam pembangunan, Penataan dan pengelolaan Boulevard dan Daerah Aliran Sungai (DAS), yang membutuhkan akses informasi yang memadai, Kondisi budaya kerja yang belum terbangun dengan kuat, dan sumber daya manusia yang menguasai TI belum merata, dan Walaupun dari segi pendidikan formal sudah memadai, namun keterampilan dan keahlian teknis dirasakan masih kurang. (Dinas KOMINFO Manado, 2010)

Permasalahan internal Instansi Dinas Komunikasi dan Informatika Kota Manado inilah yang menjadi hal penting dilakukan penelitian yakni bagaimana melakukan assessment tingkat kematangan TI. Sedangkan tujuan penelitian ini adalah menggunakan Framework COBIT 5 dalam melakukan assessment tingkat kematangan TI dan menghasilkan nilai tingkat kematangan saat ini (as-is) dari proses assessment dengan Framework COBIT 5

\section{LANDASAN TEORI}

\section{A. Tata Kelola TI}

(Surendro, 2009) Definisi tata kelola TI telah dikemukakan oleh para ahli, diantaranya sebagai berikut:

1) Kapasitas organisasi untuk mengendalikan formulasi dan implementasi strategi TI dan mengarahkan kepada kepentingan pencapaian daya saing korporasi (The 
Ministry of International Trade \& Industry:1999)

2) Tata kelola TI adalah pertanggungjawaban dewan direksi dan manajemen eksekutif. Hal ini, merupakan bagian yang terintegrasi dengan tata kelola perusahaan dan berisi kepemimpinan dan struktur serta proses organisasi yang menjamin bahwa organisasi TI mengandung dan mendukung strategi serta tujuan bisnis (IT Governance Institute:2001)

3) Tata kelola TI adalah penilaian kapasitas organisasi oleh dewan direksi, manajemen eksekutif, manajemen TI untuk mengendalikan formulasi dan implementasi strategi TI dalam rangka mendukung bisnisnya (Van Grembergen:2002).

Dari ketiga definisi tersebut dapat disimpulkan bahwa yang dimaksud dengan tata kelola TI adalah upaya menjamin pengelolaan TI agar mendukung bahkan selaras dengan strategi bisnis suatu enterprise yang dilakukan oleh dewan direksi, manajemen eksekutif, dan juga oleh manajemen TI. Tidak semua perusahaan berhasil menerapkan TI pada perusahaannya. Hal ini dapat dikarenakan tata kelola TI yang kurang baik. Tata kelola TI adalah bertujuan untuk memastikan sasaran dan harapan dari penerapan TI tercapai.

\section{B. COBIT 5}

COBIT (Control Objective for Information and Related Technology) Dikeluarkan dan disusun oleh IT Governance Institute yang merupakan bagian dari ISACA (Information Systems Audit and Control Association) pada tahun 1996. Hingga saat artikel ini dimuat setidaknya sudah ada 5 versi COBIT yang sudah diterbitkan. Dapat dilihat pada gambar 2.1 Evolusi COBIT.

Pada gambar Evolusi COBIT menjelaskan proses COBIT versi pertama diterbitkan pada tahun 1996 dikhususnya untuk para auditor, versi kedua tahun 1998 ditambahkan practice control dan control activities yang diperkenankan, versi 3.0 di tahun 2000 dimasukan management guidline, COBIT 4.0/4.1 pada tahun 2005/2007 ditambahkan Risk IT, Val IT, BMIS. Dan yang terakhir ini adalah COBIT versi 5 yang di rilis pada tahun 2012 ditambahkan 3 volume yaitu, Framework, Process preference Guide, and Implementation Guide dalam pemisahan antara Governance dan Management. (Isaca \& Sabilillah, 2013). Menjelaskan bahwa COBIT 5 framework memiliki 2 (dua) Area aktivitas utama yakni area governance dan management. Area governance memiliki satu domain yakni EDM (Evaluate, Direct, Monitor) dengan 5 domain yang masing-masing

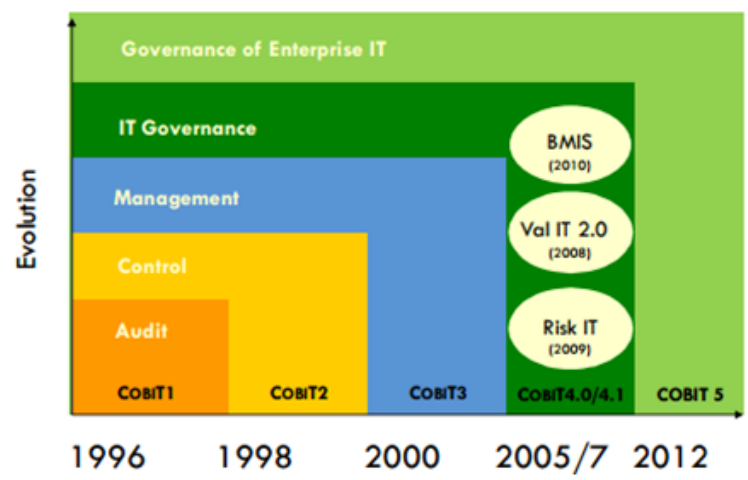

Gambar 2.1 Evolusi COBIT [Sumber: An Business Framework from ISACA at www.isaca.org/cobit (2013)]

mencakup penjelasan rinci dan termasuk panduan secara luas dan bertujuan sebagai tata kelola dan manajemen IT perusahaan. Setiap proses memiliki beberapa process practice atau governance practice. Sedangkan area management (PBRM) terdiri dari 4 (empat) domain yakni APO (Align, Plan and Organise), BAI (Build, Acquire and Implement), DSS (Deliver, Service and Support) dan MEA (Monitor, Evaluate and Assess) dengan total 37 proses. Setiap proses memiliki beberapa process practice atau management process.

Pada penelitian ini mengambil diantara dua area Governance dan Management yaitu 2 (dua) domain dari governance penulis menggunakan domain EDM (Evaluate, Direct and Monitor) dan manajement penulis mengambil domain DSS (Deliver, Service and Support), Alasan penulis mengambil kedua domain diatas adalah meneliti bagimana arah Governance dan Management pada Dinas Kominfo Kota Manado karena 2 hal ini adalah inti dari Tata Kelola TI. Pemisahan antara Governance dan Management (Indrajit, 2016) Menjelaskan bahwa Fungsi Governance adalah memastikan bahwa TI yang dimiliki perusahaan atau instansi benar - benar memberikan nilai tambah atau manfaat bagi bisnisnya, sedangkan fungsi Management adalah menjalankanya. Berikut Semua proses yang penulis gunakan semua ada 11 Proses dari 2 (dua) Domain yang dipilih.

1) Domain Evaluate, Direct, and Monitor (EDM), terdiri dari 5 (lima) proses yaitu EDM01 Ensure governance framework setting and maintenance, EDM02 Ensure benefits delivery, EDM03Ensure risk optimization, EDM04 Ensure resource optimization, dan EDM05 Ensure stakeholder Transparency 
2) Domain Deliver, Service, and Support (DSS), terdiri dari 6 (enam) proses yaitu DSS01 Manage operations, DSS02 Manage service requests and incidents, DSS03 Manage problems, DSS04 Manage continuity, DSS05 Manage security services, dan DSS06 Manage business process Control.

\section{Penelitian Terdahulu}

Terdapat beberapa penelitian sebelumnya yang menjadi tinjauan dalam pengukuran tingkat kematangan TI pada perusahaan maupun instansi pemerintahan. Sebagai bahan tinjauan dalam penelitian ini akan dicantumkan beberapa hasil penelitian sebelumnya yang dilakukan oleh beberapa peneliti,

1) (Lulu, 2013), Telah melakukan Penelitian "Analisa Teori Governance Menggunakan COBIT 5" penelitian ini membahas tentang Tata Kelola TI dalam sebuah perusahaan merupakan bagian yang tidak terlepas dari tata kelola perusahaan. Tata Kelola TI sebagai bagian proses perencanaan dan pelaksanaan IT dapat menggunakan COBIT 5. Hubungan dengan penelitian ini adalah kesepahaman dalam konsep COBIT 5 untuk melakukan penilaian tata kelola. Berbeda dengan penelitian (Lulu,2013) yang melakukan penelitian terhadap teori COBIT pada penelitian saya melanjutkan ketingkat assessment tingkat kematangan.

2) (Hakim, et al, 2014), Telah melakukan penelitian dengan judul "Evaluasi tata kelola teknologi informasi dengan framework COBIT 5 di Kementrian ESDM (studi kasus pada pusat data dan teknologi informasi ESDM)". Pada penelitian ini penulis membahas bagaimana tata kelola TI di kementrian energi dan sumber daya mineral, yang dilakukan oleh pusat data dan TI ESDM sebagai NOC, yang bertujuan untuk mengetahui sejauh mana pengelolaan dan pemanfaatan TI dalam meningkatkan pelayanan TI di KESDM dan merekomendasikan usulan kebijakan pengelolaan TI yang efekif dan efisien dengan menggunakan COBIT 5 dengan 25 sub domain mengenai data. Kesamaan penelitian adalah dengan pengukuran kematangan atau kapabilitas perbedaan penelitian saya hanya menganalisa kematangan saat ini (as-is) sedangkan (Hakim,2014) melakukan analisis gap sebagai pembanding hasil kematangannya.
3) (Pasquini \& Galiè, 2013), Telah melakukan penelitian dengan judul penelitian "COBIT 5 and the Process Capability Model. Improvements Provided for IT Governance Process". Penelitian ini masih membahas tentang perbandingan antara metode praktik COBIT dan metode lainnya berikut masalah yang di ambil oleh penulis, IT governance dan manajemen di suatu perusahaan memainkan peran penting dalam menghasilkan nilai bagi para pemangku kepentingan. COBIT 5 adalah kerangka untuk tata kelola dan manajemen perusahaan IT. Hungungan penelitian ini dengan penelitian yang saya ambil yaitu masih sama dalam penggunakan framework beserta dengan penggunaan metode perhitungan namun, hanya dibedakan pada penelitian oleh Alex dan Emidio ini menggunakan ratting scale dalam perhitungan, namun dalam pemberian rekomendasi masih sama mengacu pada hasil kematangan.

\section{METODOLOGI PENELITIAN}

Pada bagian ini menjelaskan Kerangka pemikiran dimana terdapat rincian tentang bahan atau materi, alat, urutan langkah-langkah yang dibuat secara sistematis, logis sehingga dapat dijadikan pedoman yang jelas dan mudah untuk menyelesaikan permasalahan, analisis hasil dan kesulitan-kesulitan yang dihadapi. Urutan langkah-langkah penelitian penyelesaian masalah dapat dilihat pada gambar 3.1

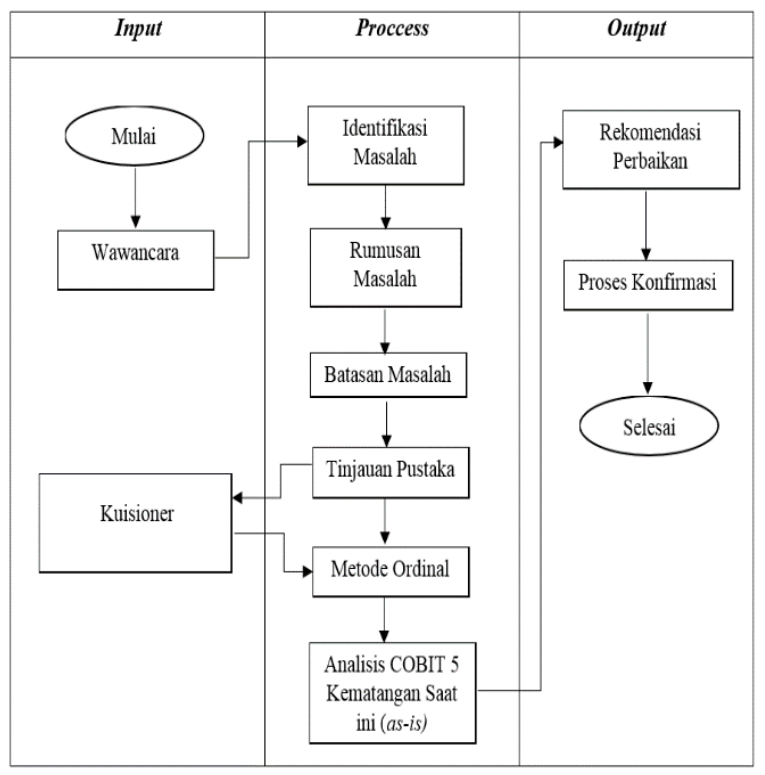

Gambar 3.1 Alur Penelitian 
Tedi Sahbudin Agoan - Analisa Tingkat Kematangan Teknologi Informasi Pada Dinas Komunikasi Dan Informatika Kota Manado Menggunakan Framework COBIT 5 Domain Evaluate, Deirect, Monitor (EDM) dan Deliver, Service, and Support (DSS)

\section{A. Wawancara}

Pengumpulan data melalui wawancara dilakukan dalam melengkapi data juga merupakan proses awal untuk identifikasi permasalahan yang ada pada instansi dalam langkah melakukan penelitian. Dalam penelitian diambil data dari wawancara sebanyak 4 responden yakni Kepala Dinas, Sekretaris Dinas dan Kabag Pengembangan Sistem Informasi dan Telematika, dan Kabag Pengawasan dan pelayanan Jasa komunikasi.

\section{B. Identifikasi Masalah}

Penyediaan sarana dan prasarana dan sumber daya manusia, teridentifikasi masih menjadi masalah yang paling utama pada DISKOMINFO Kota Manado maka dari itu, perlu:

1) Pengukuran kematangan Tata Kelola TI dalam proses kerja instansi.

2) Model Framework COBIT 5 cocok dalam pengukuran tingkat kematangan TI dalam Instansi

\section{Rumusan Masalah}

Rumusan masalah masuk dalam Input Proccess. Rumusan masalah berdasarkan latar belakang penelitian:

1) Bagaimana menganalisa tingkat kematangan organisasi pada Dinas Komunikasi dan Informatika Kota Manado dengan menggunakan Framework COBIT 5?

2) Bagaimana rekomendasi yang dapat dibentuk berdasarkan hasil dan analisis dengan menggunakan COBIT 5 tersebut?

\section{Batasan Masalah}

Batasan masalah masuk dalam Input Proccess. Pada batasan masalah penulis membatasi penelitian hanya menggunakan 2 (dua) Domain pada COBIT 5 yaitu Domain EDM dan DSS dan pada hasil pengukuran tingkat kematangan hanya pada kematangan saat ini $(a s-i s)$.

\section{E. Tinjauan Pustaka}

Tinjauan masalah masuk dalam Input Proccess. Pada Tinjauan Pustaka terdapat dua cara yang penulis lakukan yaitu:

1) Telaah Dokumen Bisnis

Proses ini dilakukan dengan meninjau sejarah perusahan sebagai objek yang akan diteliti.

2) Studi Literatur

Proses studi literatur yang dilakukan disini adalah mereviu paper penelitian sebelumnya yang berkaitan dengan COBIT 5.

\section{Kuisioner (Penelitian kuantitatif)}

Tabel 3.1 Tabel

\begin{tabular}{ll}
\hline \multicolumn{1}{c}{ RACI respondent } & \multicolumn{1}{c}{ Actual responden } \\
\hline Chief Executive Officer & - \\
Chief Information Officer & Kepala Dinas \\
Business Process & -Sekretaris Dinas, \\
& -Kabag Pengembangan \\
& Sarana Komunikasi, \\
& -Kabag Pengembangan \\
& Sistem Informasi dan \\
& Telematika, \\
& -Kabag Pengawasan \\
& dan pelayanan Jasa \\
& komunikasi \\
Head Operation & - \\
Chief architect & - \\
Head IT Administration & - \\
Compliance, Audit, Risk and & - \\
Security & \\
Staff & Pegawai / seksi-seksi \\
\hline
\end{tabular}

Kuisioner Penelitian masuk dalam Tahapan Input yang dimana dalam penelitian ini jumlah responden telah diketahui sebanya 26 responden yang nantinya semua akan dibagikan kuisioner. Responden yang dipilih oleh penulis adalah responden yang mewakili table RACI (Responsibility, Accountability, Consult, and Inform) pada proses pengolahan data (IT Governance Institute, 2007). Dapat dilihat pada Tabel 3.1 RACI Dinas Kominfo.

\section{F. Metode Ordinal}

Dalam penelitian ini adalah bagian dari Proccess penulis menggunakan metode Ordinal Dengan model teknik pengukuran ordinal dalam pembuatan kuisioner menggunakan skala likert. Ukuran ordinal adalah angka yang diberikan dimana angka-angka tersebut mengandung pengertian tingkatan. Ukuran nominal digunakan untuk mengerutkan obyek dari tingkatan terendah sampai tertinggi. Ukuran ini tidak memberikan nilai absolut terhadap obyek, tetapi hanya memberikan urutan (rangking) saja. Set obyek (nilai rangking) diberi nomor 1 = Sangat Tidak Setuju, 2 = Tidak Setuju, 3 = Ragu-Ragu, $4=$ Setuju, dan $5=$ Sangat Setuju. Sedangkan nilai absolut yang merupakan nilai model capability diberi nomor $0=$ Proses Tidak Lengkap, 1 = Proses Dijalankan, 2 = Proses Diatur, 3 = Proses Tetap, $4=$ Proses Sudah di Ukur, 5 = Proses Optimasi.

Korespondensi antara set obyek (Nilai Rangking) dengan nilai absolut (Model Maturity) dilakukan dengan cara melakukan perhitungan dalam bentuk indeks dengan rumus dibawah ini. 


$$
\text { Indeks }=\frac{\sum(\text { Jawaban })}{\sum(\text { Pertanyaan Kuisioner })}
$$

Kemudian untuk Standar tingkat kematangan yang dijadikan standar Model Maturity merujuk pada dokumen ISACA seperti pada tabel 3.2 Tingkat Maturity Model.

Skala pembulatan indeks pada tabel 3.4 adalah apabila hasil dari perhitungan dari kuisioner setelah dijumlahkan dan menghasilkan nilai dalam bentuk bilangan bulat maka dilakukan skala pembulatan dengan contoh seperti pada tabel, karena penentuan tingkat maturity hanya menggunakan nilai real demi mempermudah dalam penghitungan dan proses perekomendasian yang nantinya dari hasil pengelolaan data kuisioner dan wawancara kemudian dari hasil analisa diperoleh dilakukan pembuatan rekomendasi dari temuan untuk perbaikan instansi kedepanya. Merujuk pada tabel 3.4 Skala Pembulatan

\begin{tabular}{|c|c|}
\hline Index & Tingkat Maturity Model \\
\hline $\mathbf{0}$ & $\begin{array}{l}\text { Incomplete Process (Proses Tidak } \\
\text { Lengkap) }\end{array}$ \\
\hline 1 & Performed Process (Proses Dijalankan) \\
\hline 2 & Managed Process (Proses Diatur) \\
\hline 3 & Established Process (Proses Tetap) \\
\hline 4 & Predictable Process (Proses Di Ukur) \\
\hline 5 & Optimising Process (Proses Optimasi) \\
\hline
\end{tabular}
indeks.

Tabel 3.2. Tingkat Maturity Model (ISACA, 2013)

Tabel 3.3. Skala Pembulatan Indeks

\begin{tabular}{cc}
\hline Skala Pembulatan & Tingkat Maturity Model \\
\hline $4,51-5,0$ & $\mathbf{5}$ \\
$3,51-4,5$ & $\mathbf{4}$ \\
$2,51-3,5$ & $\mathbf{3}$ \\
$1,51-2,5$ & $\mathbf{2}$ \\
$0,51-1,5$ & $\mathbf{1}$ \\
$0-0,5$ & $\mathbf{0}$ \\
\hline
\end{tabular}

\section{G. Analisis COBIT 5}

Analisis COBIT 5 ini masuk dalam Alur Proccess dimana disini adalah proses penghitungan hasil kuisioner dan wawancara dengan menggunakan metode ordinal.

\section{H. Rekomendasi Perbaikan}

Tahap ini sudah pada proses output. Sudah pada tahap pemberian rekomendasi merujuk pada hasil dari analisis kuisioner COBIT 5, yang kemudian rekomendasi perbaikan ini adalah saran - saran perbaikan yang sesuai dengan penjelasan COBIT 5 untuk diberikan kepada Dinas Komunikasi dan Informatika Kota Manado.

\section{Proses Konfirmasi}

Tahap ini adalah tahap akhir dari proses output penelitian. Proses Konfirmasi setelah dibuatkan Rekomendasi Perbaikan yang nantinya akan disampaikan ke Instansi pada penelitian ini yakni pada Dinas Komunikasi dan Informatika Kota Manado dimana Penulis akan melakukan wawancara konfirmasi kepada Kepala Dinas atau kepada yang paling berwenang sesuai keputusan Kepala Dinas dalam menentukan pilihan, untuk memastikan pada level berapakah penerapan implementasi Tata Kelola TI yang sudah berjalan, maka setelah diketahui dan dicoba di arahkan untuk level mengukuti level COBIT 5 yaitu dari Nilai $0-5$ dan juga penjelasan setiap level kematangannya.

\section{HASIL DAN PEMBAHASAN}

\section{A. Hasil Domain EDM}

Tabel 4.1 Kalkulasi Tingkat kematangan (as-is), setiap domain EDM

\begin{tabular}{rccc}
\hline EDM & & Indeks & Maturity Level \\
& & & \\
\hline EDM01 & as $-i s$ & 2.61 & $\mathbf{3}$ \\
EDM02 & as $-i s$ & 2.83 & $\mathbf{3}$ \\
& & & \\
EDM03 & as $-i s$ & 2.36 & $\mathbf{2}$ \\
& & & $\mathbf{2}$ \\
EDM04 & as $-i s$ & 2.40 & $\mathbf{3}$ \\
& & & \\
\hline
\end{tabular}




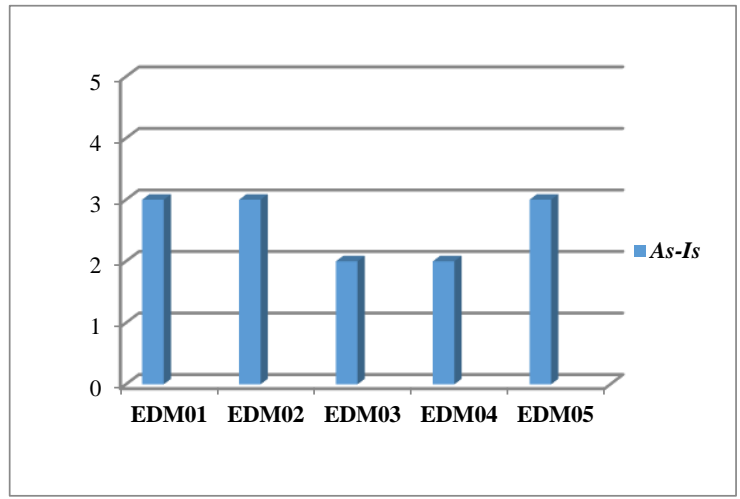

Gambar 4.1. Grafik Tingkat Kematangan TI as - is domain EDM

\section{B. Hasil Domain DSS}

Tabel 4.2 Kalkulasi Tingkat kematangan (as-is), setiap domain DSS

\begin{tabular}{cccc}
\hline DSS & Indeks & $\begin{array}{c}\text { Maturity } \\
\text { Level }\end{array}$ \\
\hline DSS01 & as $-i s$ & 2.52 & $\mathbf{3}$ \\
DSS02 & as $-i s$ & 2.22 & $\mathbf{2}$ \\
DSS03 & as $-i s$ & 2.36 & $\mathbf{2}$ \\
DSS04 & as $-i s$ & 2.52 & $\mathbf{3}$ \\
DSS05 & as $-i s$ & 2.26 & $\mathbf{2}$ \\
DSS06 & as $-i s$ & 2.49 & $\mathbf{2}$ \\
\hline
\end{tabular}

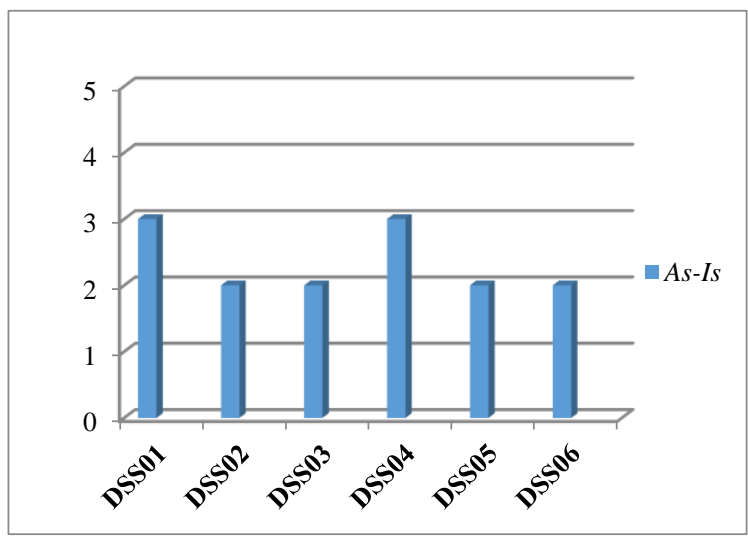

Gambar 4.2. Grafik Tingkat Kematangan TI (as - is) Domain DSS COBIT 5

\section{Rekomendasi Perbaikan}

1) Rekomendasi EDM01

Berdasarkan analisis Hasil Wawancara dan Tingkat Kematangan saat ini (as - is) yang didapat dengan level target yang ingin dicapai pada EDM01 yang telah mencapai Established Process, maka berikut adalah rekomendasi yang dapat penulis berikan pada Dinas Kominfo Kota Manado

a) Mengevaluasi proses strategi IT dalam pengambilan keputusan pengoptimalan TI dalam Instansi, meski sekarang ini proses TI dalam Instansi sudah mencapai proses tetap, maka untuk mencapai proses yang diharapkan yakni pada proses predictable process atau proses yang sudah diukur perlu diadakan evaluasi dalam sistem secara berkala.

b) Memonitor setiap pelaksanaan dan kebijakan dalam menentukan arah peran tata kelola sebagaimana dalam masalah yang dihadapi oleh instansi yaitu terjadi kesenjangan akses informasi sehingga belum mendukung Kota Manado memasuki komunitas informasi global.

\section{2) Rekomendasi EDM02}

Berdasarkan analisis Hasil Wawancara dan Tingkat Kematangan saat ini (as - is) pada EDM02 yakni sudah pada level 3 atau Established Process, maka berikut adalah rekomendasi yang dapat penulis berikan pada Dinas Kominfo Kota Manado

a) Melakukan peninjauan nilai atau manfaat dari pengadaan perangkat TI untuk mengetahui seberapa besar manfaat TI dalam proses keseluruhan dalam instansi, baik itu pengecekan harian, mingguan, maupun sebulan sekali.

b) Melakukan tindakan atau gerak cepat dalam hal perencanaan program kerja, investasi, pembiayaan, maupun resiko, untuk melihat bagaimana manfaat dari penggunaan TI sebagai penunjang kinerja dalam menuju tingkat predictable process (Proses diukur)

3) Rekomendasi EDM03

Berdasarkan analisis Hasil Wawancara dan Tingkat Kematangan saat ini (as - is) pada EDM03 yakni pada level 2 (Managed Process Proses Teratur), maka berikut adalah rekomendasi 
yang dapat penulis berikan pada Dinas Kominfo Kota Manado.

a) Instansi harus melakukan evaluasi pada manajemen resiko untuk memastikan dengan peran TI dapat mengetahui kerugian terhadap asset, dan diketahui oleh pimpinan sebagai pemegang pengawasan terhadap tata kelola.

b) Permasalahan yang masih menonjol pada Dinas Kominfo sendiri yakni kondisi budaya kerja yang belum kuat, seperti penguasaan Teknologi Informasi yang masih kurang. Maka, perlu penguatan dalam majemen untuk melakukan rekrutmen ASN berlatar belakang IT dalam mencapai target proses yang terukur atau predictable process.

4) Rekomendasi EDM04

Berdasarkan analisis Hasil Wawancara dan Tingkat Kematangan saat ini (as - is) pada EDM04 yakni sudah pada level 2 atau (Managed Process - Proses teratur), maka berikut adalah rekomendasi yang dapat penulis berikan pada Dinas Kominfo Kota Manado

a) Masalah yang harus paling di perhatiakan dalam dinas komunikasi sesuai dengan kajian terhadap dokumen bisnis RENSTRA yaitu dalam pengelolaan sumber saya manusia, untuk mencapai target proses terukur atau predictable process maka perlu adanya pengoptimalan sumberdaya manusia yang menguasai TIK serta dinilai mampu untuk mengelola Cammand Centre

b) Instansi harus melakukan gerakan ahli bidang TIK outsourching atau pelaksanaan perekrutan tenaga harian lepas (kontrak), dibidang TIK jika dalam instansi masih ada keterbatasan sumber daya.

5) Rekomendasi EDM05

Berdasarkan analisis Hasil Wawancara dan Tingkat Kematangan saat ini (as - is) pada EDM05 yakni sudah pada level 3 atau (Established Process - Proses tetap), maka berikut adalah rekomendasi yang dapat penulis berikan pada Dinas Kominfo Kota Manado

a) Peningkatan transparansi antara pemerintah dan sektor swasta (stakeholder) dengan melakukan pertemuan dan rapat koordinasi secara rutin.

b) Memonitor tahap simulasi dalam setiap implementasi kerja antara pemerintah dan sektor swasta, untuk memastikan kriteria persyaratan TI terpenuhi dalam rangka adanya keterlibatan sektor swasta dalam mendukung program atau kegiatan skala kota.

6) Rekomendasi DSS01

Berdasarkan analisis Hasil Wawancara dan Tingkat Kematangan saat ini (as - is) pada DSS01 yakni sudah pada level 3 atau (Established Process - Proses tetap), maka berikut adalah rekomendasi yang dapat penulis berikan pada Dinas Kominfo Kota Manado

a) Instansi pada tahap ini sudah menjalankan proses penjadwalan aktivitas operasional TI terstruktur dengan tetap dan menginginkan proses secara terukur maka harus melakukan perbaikan pada performa, sumber daya, pengadaan fasilitas yang dibutuhkan dan lengkap, dan dapat menghasilkan peningkatan yang menjadi tujuan dari instansi.

b) Melakukan maintenance rutin mingguan pada aset prasarana yang membutuhkan pengawasan ekstra berhubungan dengan IT Aset.

7) Rekomendasi DSS02

Berdasarkan analisis Hasil Wawancara dan Tingkat Kematangan saat ini (as - is) pada DSS02 yakni sudah pada level 2 atau (Managed Process - Proses Teratur), maka berikut adalah rekomendasi yang dapat penulis berikan pada Dinas Kominfo Kota Manado

a) Melakukan dokumentasi jenis - jenis insiden, kemudian selalu di evaluasi untuk mempermudah dalam memetakanya.

b) Melakukan klarifikasi terhadap insiden yang dilayani, sehingga mudah dalam penanganan yang efektif. Dan membuat strategi dalam pembuatan layanan dan pemecahan insiden yang baik dan bentuk kebijakan ataupun tindakan penanganan langsung pada sistem yang bermasalah

8) Rekomendasi DSS03

Berdasarkan analisis Hasil Wawancara dan Tingkat Kematangan saat ini (as - is) pada DSS03 yakni sudah pada level 2 atau (Managed Process - Proses Teratur), maka berikut adalah rekomendasi yang dapat penulis berikan pada Dinas Kominfo Kota Manado 
a) Melakukan identifikasi terhadap kinerja penyelesaian masalah baik itu akses data, aset IT yang telah ditentukan.

b) Setiap aktivitas agar tidak terjadi kekeliruan, didokumentasikan dan menganalisa kembali laporan masalah baik masalah yang Belum selesai di tangani maupun yang sudah di tangani, agar tidak terjadi lagi masalah yang serupa.

9) Rekomendasi DSS04

Berdasarkan analisis Hasil Wawancara dan Tingkat Kematangan saat ini (as - is) pada DSS04 yakni sudah pada level 3 atau (Established Process - Proses Tetap), maka berikut adalah rekomendasi yang dapat penulis berikan pada Dinas Kominfo Kota Manado

a) Mengkaji secara rutin apakah proses bisnis TI sudah masuk proses tetap untuk menuju proses yang sudah diukur artinya proses ini sudah pada tahap menghasilkan kinerja yang berkelanjutan.

b) Mengukur kembali kesesuaian TI apakah proses sudah menunjang keberlangsungan proses bisnis dan sudah menghasilkan.

10) Rekomendasi DSS05

Berdasarkan analisis Hasil Wawancara dan Tingkat Kematangan saat ini (as - is) pada DSS05 yakni sudah pada level 2 atau (Managed Process - Proses Teratur), maka berikut adalah rekomendasi yang dapat penulis berikan pada Dinas Kominfo Kota Manado

a) Melakukan Pertemuan pembahasan report untuk mengetahui sampai dimana hasil, maupun permasalahan yang sudah ditemukan sebelumnya.

b) Memberikan peringatan kepada pengguna/ staf, untuk standar dasar keamanan data di dalam perangkat yang dimiliki.

\section{1) Rekomendasi DSS06}

Berdasarkan analisis Hasil Wawancara dan Tingkat Kematangan saat ini (as - is) pada DSS06 yakni sudah pada level 2 atau (Managed Process - Proses Teratur), maka berikut adalah rekomendasi yang dapat penulis berikan pada Dinas Kominfo Kota Manado

a) Menjalankan proses sasaran dan tujuan dalam pengembangan sarana dalam pengembangan Kota berbasis teknologi baik dari hulu sampai ke hilir dalam mengidentifikasi peluang untuk pengembangan kota.

b) Mengikuti pelatihan khusus keamanan sistem TI, kerahasiaan data, dan kesiagaan insiden yang nanti akan timbul.

\section{KESIMPULAN}

\section{A. Kesimpulan}

Berdasarkan penelitian yang dilakukan pada Dinas Komunikasi dan Informatika Kota Manado dari hasil Assessment Tingkat Kematangan TI, maka kesimpulan dari tugas Akhir ini adalah

1) Dari hasil tingkat kematangan yang dihasilkan diketahui bahwa tingkat kematangan saat ini (as-is) untuk domain EDM (Governance) rata - rata mencapai tingkat (3 - Established Process) berarti proses sudah pada tahap yang Tetap diinstansi sudah pada tahap implementasi proses - proses terstandar, artinya sudah ada standar proses IT yang berlaku disetiap diseluruh lingkup organisasi artinya Dinas Kominfo dari segi tatanan strategis sudah pada tahap yang Stabil atau Established Proccess. Sedangkan Domain DSS (Management), tingkat kematangan rata rata baru mencapai tingkat $(2-$ Managed Proccess) yang artinya masih pada proses Teratur artinya instansi sudah menjalankan tugas proses TI dan telah mencapai tujuannya secara terkelola dengan baik melalui tahapan perencanaan, evaluasi dan penyesuaian kearah yang lebih baik lagi.

2) Setiap proses subdomain pada kedua domain diberikan rekomendasi perbaikan yang nantinya bisa mempengaruhi tingkat kematangan saat ini untuk menuju tingkat perbaikan dan sampai pada kematangan yang ingin dicapai berikut untuk meningkatkan proses kinerja instansi kearah yang lebih baik.

3) Pemberian rekomendasi adalah berdasarkan pada level COBIT 5 dan juga mengacu pada fungsi dari Governance yakni memastikan bahwa Proses TI yang dimiliki instansi benar - benar memberikan nilai tambah bagi bisnis, dan Management yakni yang menjalankannya.

\section{B. Saran Pengembangan}

1) Saran pengembangan penelitian ini bisa dilakukan lagi ke area Governance dan Management lain pada COBIT 5 serta dengan 
penilaian menggunakan balanced scorecard dan rating sale

\section{DAFTAR PUSTAKA}

[1] Boar, Bernard, The Art of Strategic Planning for Information Technology. Second Edition. New York: John Wiley \& Sons, Inc, 2001. Chapter 3, Hal. 14.

[2] Hakim, A, Saragih, A. S. (2014). Evaluasi Tata Kelola Teknologi Informasi Dengan Framwork Cobit. 5 Di Kementerian Esdm. Journal of Information Systems, 10(2), 105-117. https://doi.org/10.1017/CBO9781107415324.0 04

[3] ISACA, \& Sabilillah, R. R. (2013). COBIT Self-assessment Guide: Using COBIT 5.

[4] ISACA. COBIT ®5 (2013). Enabling Proceses. IT Governance Intitute (ITGI), Rolling Meadows, USA.

[5] ISACA. COBIT ®5: (2013) "Introduction COBIT5". IT Governance Intitute (ITGI), Rolling Meadows, USA.

[6] Lulu, D. Y. (2013). Analisa Teori IT Governance menggunakan COBIT 5. Teknik Elektro Dan Komputer, I(I), 99-106.

[7] Pasquini, A., \& Galiè, E. (2013). COBIT 5 and the Process Capability Model. Improvements Provided for IT Governance Process. Proceedings of FIKUSZ '13 Symposium for Young Researchers, 67-76. Retrieved from https://kgk.uniobuda.hu/sites/default/files/06_Pasquini_Galie. pdf.

[8] Solikin, (2008). "Model Audit Sistem Informasi di Perguruan Tinggi Menggunakan kerangka Kerja COBIT". KNSI 2007, STMIK “AMIK Bandung", Indonesia.

[9] Surendro, Kridanto (2009), "Implementasi Tata Kelola Teknologi Informasi", Edisi 1st, Bandung: Informatika.

10] Tim Penyusun. (2010). "Renstra - Tujuan dan Strategi 2016-2021" Dinas Komunikasi Dan Informatika Kota Manado.

[11] Tim Penyusun. (2016), "Rencana Pembangunan Jangka Menengah Daerah Kota Manado Periode 2016 - 2021”, Pemkot Manado.

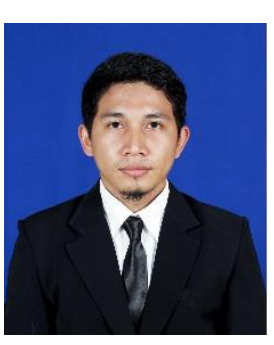

Tedi Sahbudin Agoan, lahir di Bintau', Kabupaten Bolaang Mongondow, Provinsi Sulawesi Utara. Anak ke-1 dari 3 bersaudara dengan pendidikan Sekolah Dasar Bintau'. Penulis lalu melanjutkan ke Sekolah Menengah Pertama Negeri 2 Passi. Lalu ke SMK Ti Cokroaminoto Kotamobagu dengan Jurusan Teknik Komputer dan Jaringan. Pada tahun 2011 melanjutkan ke Perguruan Tinggi di Universitas Sam Ratulangi dengan mengambil Jurusan Teknik Informatika. Pada Tahun 2015 bulan Februari sampai Bulan Maret melakukan Kerja Praktek di SMA Negeri 4 Manado dengan Judul Projek Membuat website Sekolah SMA Negeri 4 Manado. Dan Pada Tahun 2015 bulan Juli, penulis membuat Skripsi demi memenuhi Syarat Sarjana (S1) dengan penelitian berjudul Analisa Tingkat Kematangan Teknologi Informasi Menggunakan Framework COBIT 5, yang dibimbing oleh dua dosen pembimbing yaitu Ir. Hans F. Wowor, M.Kom dan Stanley D.S. Karouw.ST, MTI sehingga pada tanggal 26 Januari 2017 penulis resmi lulus di Teknik Informatika Universitas Sam Ratulangi Manado menyandang gelar Sarjana Komputer dengan Predikat Sangat Memuaskan. 